\title{
Detection to trace aluminum ion of pharmaceutical wastewater using synthesis of Schiff-based chemosensor
}

\author{
Mengistu Jemberu Dagnaw ${ }^{*}{ }^{(0)}$ Mahesh Gopal ${ }^{(\infty}$ \\ Department of Mechanical Engineering, Institute of Engineering and Technology, Wollega University, Post Box No.395, Nekemte, Ethiopia
}

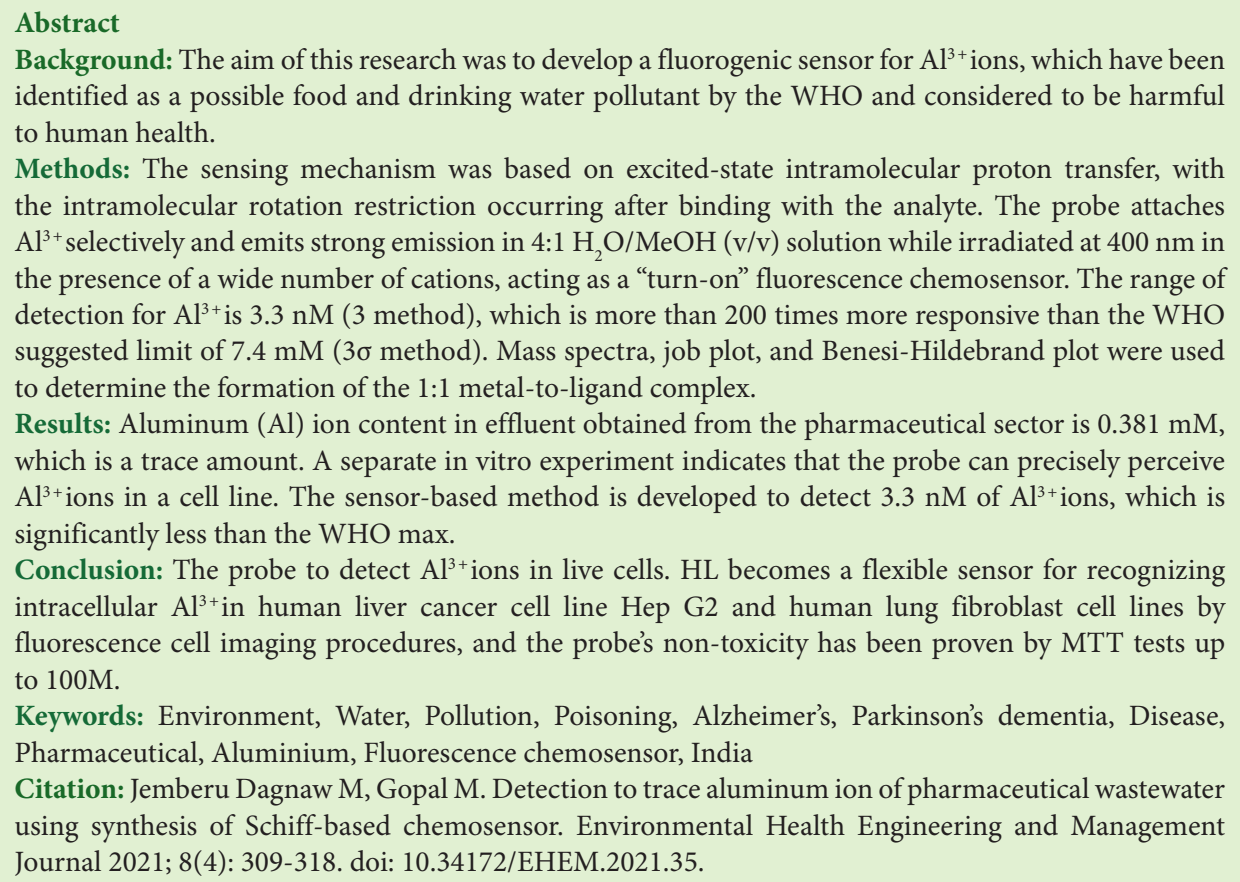

Background: The aim of this research was to develop a fluorogenic sensor for $\mathrm{Al}^{3+}$ ions, which have been identified as a possible food and drinking water pollutant by the WHO and considered to be harmful to human health.

Methods: The sensing mechanism was based on excited-state intramolecular proton transfer, with the intramolecular rotation restriction occurring after binding with the analyte. The probe attaches $\mathrm{Al}^{3+}$ selectively and emits strong emission in $4: 1 \mathrm{H}_{2} \mathrm{O} / \mathrm{MeOH}(\mathrm{v} / \mathrm{v})$ solution while irradiated at $400 \mathrm{~nm}$ in the presence of a wide number of cations, acting as a "turn-on" fluorescence chemosensor. The range of detection for $\mathrm{Al}^{3+}$ is $3.3 \mathrm{nM}$ ( 3 method), which is more than 200 times more responsive than the WHO suggested limit of $7.4 \mathrm{mM}$ ( $3 \sigma$ method). Mass spectra, job plot, and Benesi-Hildebrand plot were used to determine the formation of the 1:1 metal-to-ligand complex.

Results: Aluminum (Al) ion content in effluent obtained from the pharmaceutical sector is $0.381 \mathrm{mM}$, which is a trace amount. A separate in vitro experiment indicates that the probe can precisely perceive $\mathrm{Al}^{3+}$ ions in a cell line. The sensor-based method is developed to detect $3.3 \mathrm{nM}$ of $\mathrm{Al}^{3+}$ ions, which is significantly less than the WHO max.

Conclusion: The probe to detect $\mathrm{Al}^{3+}$ ions in live cells. HL becomes a flexible sensor for recognizing intracellular $\mathrm{Al}^{3+}$ in human liver cancer cell line Hep G2 and human lung fibroblast cell lines by fluorescence cell imaging procedures, and the probe's non-toxicity has been proven by MTT tests up to $100 \mathrm{M}$.

Keywords: Environment, Water, Pollution, Poisoning, Alzheimer's, Parkinson's dementia, Disease, Pharmaceutical, Aluminium, Fluorescence chemosensor, India

Citation: Jemberu Dagnaw M, Gopal M. Detection to trace aluminum ion of pharmaceutical wastewater using synthesis of Schiff-based chemosensor. Environmental Health Engineering and Management Journal 2021; 8(4): 309-318. doi: 10.34172/EHEM.2021.35.

Article History:

Received: 26 May 2021 Accepted: 11 July 2021

ePublished: 7 December 2021

\section{Introduction}

Aluminum (Al) is the most abundant metal on the planet's surface ( $8.3 \%$ of total metal mass). Al is released into the atmosphere as a consequence of the extraction and processing of ores, as well as the manufacture of $\mathrm{Al}$ wire, alloys, and chemicals. Fine Al particles in the air are either blown away by storms or fall to the ground. The quantity of pollution determines the toxicity of Al. Aluminium toxicity is mainly influenced by Al bioavailability, which is influenced by relatively low aluminium levels in natural sources, namely drinking water (1). Aluminium is a poisonous, insoluble, non-essential substance, which is present in most natural water that affects the human beings (2). However, acid rain, waste outflow, and soil extraction have all discharged significant amounts of $\mathrm{Al}$ into the atmosphere in recent years. The greatest concentration of $\mathrm{Al}$ in water supplies used as drinking water is $200 \mu \mathrm{g} \mathrm{L}^{-1}$ (3). Since $\mathrm{Al}$ in drinking water was largely made up of soluble species, as a result, it was thought that $\mathrm{Al}$ in drinking water will have a disproportionate impact on the Alzheimer's disease (AD) occurrence when it was consumed (4). The dialysis was performed to determine the amount of $\mathrm{Al}$ in muscle; the results revealed, that the average muscle contained 14.8 parts per million (PPM) of $\mathrm{Al}$ and the trabecular-bone contained 98.5 PPM. The uremic patient's traces are 25 ppm during dialysis, and the $\mathrm{Al}$ traces in the gray matter of the brain are greater in both patients (5). A higher incidence of dementia and $\mathrm{AD}$ has been associated with drinking water with high $\mathrm{Al}$ content $(\geq 0.1 \mathrm{mg} / \mathrm{L})$ (6). Martyn et al (7) conducted a research in different regions to find the presence of $\mathrm{Al}$ and silicon that causes the risk of $\mathrm{AD}$ in drinking water. The research showed that the higher $\mathrm{Al}$ and lower silicon concentrations in drinking water, increase the possibility of risk of $\mathrm{AD}$ at usual concentrations up to around $0.2 \mathrm{mg} / \mathrm{L}$, and it was also 
shown that drinking water with silicon contents more than $6 \mathrm{mg} / \mathrm{L}$ of molybdate-reactive silica seemed to have a protective effect. This research (8) used a random sample of 186 water utilities, with raw and completed water samples obtained five times over the course of a year and tested for iron and $\mathrm{Al}$ using the atomic absorption technique. $\mathrm{Al}$ is much almost certainly to be found in surface waters, only $9 \%$ of groundwaters contained visible levels of $\mathrm{Al}$, while $78 \%$ of surface waters have detectable Al. The goal of this study was to assess the relationship between long-term exposure to different forms of $\mathrm{Al}$ in drinking water and the beginning of $\mathrm{AD}$. The formation of $\mathrm{AD}$ has been associated with organic monomeric $\mathrm{Al}$, which creates the illness. Compared to earlier research, this relationship was discovered in a geographic environment characterized by low $\mathrm{Al}$ quantities and high $\mathrm{pH}$ levels (9). Al levels over $80 \mathrm{~g} / \mathrm{L}$ in drinking water has been related to an increased risk of $\mathrm{AD}$. The findings of this study clearly suggest that metal such as $\mathrm{Al}$ in drinking water has no role in the etiology of senile dementia (10). McLachlan et al (11) reported that there is a possibility of $\mathrm{Al}$ concentration in drinking water which causes $\mathrm{AD}$ on the basis of strict neuropathologic criteria. The results of epidemiologic research, along with a broad body of laboratory evidence of $\mathrm{Al}$ neurotoxicity and elevated concentration of silicic acid $\left(\mathrm{Si}_{2} \mathrm{OH}_{4}\right)$ would be in $\mathrm{AD}$ affected brain, suggest that lowering and retaining appropriate residual $\mathrm{Al}$ in drinking water (at least below $100 \mu \mathrm{g} / \mathrm{L}$ ) should be prioritized, particularly for older age groups at risk for AD. Al toxicity affects the plant growth but also affects the neurological system, producing diseases such as Alzheimer's and Parkinson's disease, and amyotrophic lateral sclerosis (12). Although the precise mechanism by which $\mathrm{Al}$ influences disease mechanisms remains unclear, there is an evidence that it increases oxidative stress and inflammatory events. These activities are also associated with $\mathrm{AD}$ and exposure to the metal may exacerbate the disease by enhancing these processes (13). Al fractions were measured in water samples collected from three water supply wells. All water treatment plants employed poly-Al chloride (PAC) as a coagulant; however, the Al-based coagulant had a minimal effect on the metal concentration of the raw water. Al concentrations in raw and treated water vary dramatically. More than $80 \%$ of $\mathrm{Al}$ in fresh water is in the form of particulates (14). The aim of this research was to determine the concentration of $\mathrm{Al}$ available in groundwater. Standard methods are used for the examination of water and wastewater to evaluate values of consistency factors such $\mathrm{pH}$, turbidity, total dissolved solids (TDS), and Al content in 871 water samples (15). Simulated coil-pipe tests, batch reactor tests, and quartz crystal microbalance with dissipation monitoring were used to study the deposition characteristics of various $\mathrm{Al}$ species in PAC. Under stirring conditions, more $\mathrm{Al}$ may collect on the pipe surface for $\mathrm{Al}$ species with a greater deposition tendency. For Al13 and $\mathrm{Al30}$, the $\mathrm{pH}$ impact on deposition behavior was quite modest within the neutral $\mathrm{pH}$ range of 6.7-8.7 (16). This paper discusses the environmental and clinical tests are being used to determine the risk of disease. The aim of this study was to find out more about $\mathrm{AD}$, breast cancer serving as a major endpoint. Internal Al load comparison levels ( $15 \mathrm{~g} / \mathrm{L}$ in urine, $5 \mathrm{~g} / \mathrm{L}$ in serum) are more likely to be exceeded in people who have been exposed to $\mathrm{Al}$ at work. The essential internal toxicity criteria for $\mathrm{Al}$ are found in blood and urine. For occupational exposure, the biological tolerance limit is $50 \mathrm{~g}$ of $\mathrm{Al}$ per gram of creatinine in the urine (17). The goal of this study was to determine the concentration of $\mathrm{Al}$ and cadmium $(\mathrm{Cd})$ in cigarettes and drinking water. Electrothermal atomic absorption spectrometry was used to determine the quantities of $\mathrm{Cd}$ and $\mathrm{Al}$ in cigarettes, drinking water, and blood samples. The findings revealed that the levels of $\mathrm{Al}$ and $\mathrm{Cd}$ in lake and subterranean water were higher than the WHO-recommended safe drinking water limit (18). Drinking water with fluoride and $\mathrm{Al}$ is suspected to have harmful health consequences, particularly on the brain, liver, and kidneys. The levels of blood urea and creatinine were evaluated as indications of kidney malfunction. To determine the level of damage that the $\mathrm{F}, \mathrm{Al}$, and $\mathrm{AlFx}$ complex could produce, histopathological assessments of kidney tissues were performed (19). In this study, the unique low-cost defluoridation process based on coating Al hydroxide on the surface of rice husk ash. Rice husk ash is made by burning rice/paddy husk, which is a readily available and low-cost raw material. The adsorption capacity was determined to be between 9 and $10 \mathrm{mg} / \mathrm{g}$, indicating high fluoride removal effectiveness (20). The present study contains a number of statistical benefits, such as the study size and prospective breadth, as well as well-defined illness diagnoses. Individual sociodemographic characteristics, as well as data on other important drinking water factors were analyzed to find out whether these factors may be confusing for the association between $\mathrm{Al}$ and $\mathrm{AD}$ (21). The main cause of $\mathrm{Al}$ effects on the water distribution system and human health is its speciation in drinking water. To reduce $\mathrm{Al}$ bioavailability in drinking water, orthophosphate should be added before the coagulant process, and fluoride and silicic acid concentrations should be kept below 2.0 and 25 $\mathrm{mg} / \mathrm{L}$ (22). The impact of PAC coagulant qualities on soluble residual $\mathrm{Al}$ concentrations following coagulation and filtration was investigated in this study. While by increasing the dose of normal-basicity, the polyaluminum chloride (PACls) increased the dissolved residual $\mathrm{Al}$ concentration at $\mathrm{pH} 7.5$, raising the dosage of highbasicity PACls decreased the soluble residual $\mathrm{Al}$ concentration at $\mathrm{pH}$ 7.5. The capacity of high-basicity $\mathrm{PACl}$ to minimize residual $\mathrm{Al}$ concentrations was maintained at higher raw water temperatures, despite the 
fact that residual $\mathrm{Al}$ concentrations was maintained (23). Maximum contaminant guidelines are utilized to limit pollutants in drinking water in order to prevent health problems. Al-induced bone disease may cause stress fractures in the ribs, femur, vertebrae, humerus, and metatarsals. Serum $\mathrm{Al} \geq 100 \mu \mathrm{g} / \mathrm{L}$ has a $75 \%-88 \%$ positive predictive value for $\mathrm{Al}$ bone disease. The preterm infants, infants with congenital uremia, and children and adults with kidney disease are all at increased risk of systemic $\mathrm{Al}$ poisoning following repeated intake of monomeric $\mathrm{Al}$ salts (24). Al has been hypothesized to have a role in the development of $\mathrm{AD}$. Although the precise mechanism of $\mathrm{Al}$ toxicity is unknown, growing evidence indicates that the metal may enhance oxidative and inductive reactions, ultimately leading to tissue damage. This study examines $\mathrm{Al}$ overall toxicity, with a focus on the ways through which it may hasten the development of chronic age-related neurodegenerative diseases (25). Pharmaceutical manufacturing plants contaminate plants, humans, and animals directly. The Organization for Economic Cooperation and Development (OECD) is now encouraging countries to decrease pharmaceutical production; nevertheless, the UK, Germany, and other countries that depend on pharmaceutical products for income, are reportedly still manufacturing a significant quantity of medicines (26). Large amounts of pharmaceuticals are utilized, resulting in increasing discharge into the environment. Medicines are designed to resist photodegradation, biodegradation, and chemical breakdown until they are injected and perform particular pharmacological activities; residual pharmaceutical chemicals are handled with normal water/wastewater treatment (27). In the aquatic environment, pharmaceuticals and drug metabolites have been found. Under certain recharge conditions, polar pharmaceutically active compounds (PhACs) such as clofibric acid, carbamazepine, primidone, or iodinated contrast agents may leak into groundwater aquifers. Most active medications are removed through metabolism and urine after being eaten, and PhACs have been discovered in groundwater contaminated by landfill leachates or industrial leftovers (28).

In several nations, pharmaceutical medications have been discovered in small amounts in sewage treatment plant effluents, surface waters, seawaters, groundwater, and some drinking waters. The effects of various medications on aquatic animals have been studied using acute toxicity testing. It was reported that in surface water concentrations are lower and so there is low environmental risks (29). In 2015, the global pharmaceutical business was valued US\$1.06 trillion, with an annual average growth rate of $5.2 \%$. According to estimates, North America's trade is valued US $\$ 363.2$ billion, Europe's is worth USD 315.1 billion, and Asia's market is worth US $\$ 281.3$ billion. As the pharmaceutical industrial sector in South Korea is rapidly increasing, there is an increase in people suffering from chronic diseases. With a 5-year average annual growth rate of $2.1 \%$, its gross pharmaceutical production increased by $3.4 \%$ in 2015, reaching KRW 16969.6 billion. The pharmaceutical industry is projected to continue to expand rapidly over the next five years (30). Artificial neural network models and multivariate regression models were used to study the influent characteristics of water that are measured in the Birjand Waste Stabilization Pond (WSP) in Iran, such as $\mathrm{pH}$, chemical oxygen demand, biological oxygen demand over 5 days (BOD5), total suspended solids, total dissolved solid (TDS), Electrical conductivity (EC) and turbidity , and turbidity. The pseudo-first kinetics and the Langmuir-Hinshelwood model is used to determine the extent of degradation process and the removal of $\mathrm{p}$-Nitroaniline (PNA) from aqueous solutions using novel semi-fluid $\mathrm{Fe} /$ charcoal reactor. The optimization is carried out to determine the halfway and final products in degradation reaction path (31). Khodadadi et al (32) found that TDS is considered as the most descriptive characteristic of influent wastewater to predict the WSP performance. Seven residue samples were collected from completely different locations and depths of the watercourse. The texture, clay, extractible iron and organic content of the sediments were measured. Pyrolysis-gas chromatography activity, mass spectrometry analysis showed that there are 3 types of organic substances: Crude hydrocarbons, artificial, and plant residues (33). Malakootian et al conducted a study to remove acid red 18 dye contained in wastewater, which are untreated in the aqueous environment, using hybrid micro-electrolysis process, including iron and Charcoal under the influence of ultrasonic waves (Fe/C/US) (34). The parameters affecting the adsorption process such as initial $\mathrm{pH}$ solution, adsorbent concentration, CIP concentration, and contact time are considered for experimental study. Fe3O4@SiO2-Schiff base nanocomposite (Fe3O4@ $\mathrm{SiO} 2-\mathrm{APTMS}-\mathrm{HBA}$ ) was synthesized in in this study. The results showed that the maximum removal efficiency rate is $96 \%$ under the optimum process conditions $(\mathrm{pH}$ $=7$, contact time $=5 \mathrm{~min}, \mathrm{CIP}$ concentration $=10 \mathrm{mg} / \mathrm{L}$, and adsorbent concentration $=50 \mathrm{mg} / \mathrm{L})(35) . \mathrm{Al}$ is not a biological metal that is stored in the tissues comprising nerve cells. Nerve cell transmission would be inhibited or disrupted if insoluble Al-salts are deposited. As a result, biological communication, information transfer, and other aspects of human life are severely disrupted, resulting in Al-related bone diseases, encephalopathy, myopathy, and various neurodegenerative diseases such as $\mathrm{AD}$, Parkinson's dementia, and other neurodegenerative diseases in the human body. With the increased use of $\mathrm{Al}$, it is possible the plant roots would be harmed.

In this study, a synthesized probe 1-(1-(Phenyl (pyridine-2-yl) methyl)-1H-benzo[d]imidazol-2-yl) naphthalene-2-ol was designed for the selective and 
sensitive detection of $\mathrm{Al}^{3+}$ in semi-aqueous media. During complication with $\mathrm{CH}_{3} \mathrm{CN}$, there is no proton conversion. In Hep G2 cells, the fluorescence specific concentration of HL in the presence of multiple anions, as well as the intracellular detection of $\mathrm{Al}^{3+}$ ion, was investigated.

Materials and Methods

\section{Raw materials}

All reagents and solvents used for synthesis were purchased from commercial sources and used as received. The chemicals and solvents were used in synthesis. Milli-Q water was used to render both aqueous solutions (Millipore). 2-hydroxy-1-naphthaldehyde (HNA) was purchased from Merck (Germany), and $\mathrm{Al}\left(\mathrm{NO}_{3}\right)_{3} \cdot 9 \mathrm{H}_{2} \mathrm{O}$ and Merckoglas were purchased from Merck, (Darmstadt, Germany). $\mathrm{N}^{1}$-(Phenyl (pyridine-2-yl) methyl) benzene-1, 2-diamine was synthesized using the previously mentioned method (36). All extra solutions and chemicals (AR grade) were purchased from Merck and finally used without further purification.

\section{Instruments used}

UV-VIS spectra were obtained using a Perkin Elmer Lambda 25 spectrophotometer, fluorescence spectra were obtained using a Perkin Elmer Spectro fluorometer type LS55, and FT-IR spectra ( $\mathrm{KBr}$ disc, 4000-400 $\mathrm{cm}^{-1}$ ) using a Perkin Elmer LX-1FTIR spectrophotometer. TMS was used as an internal standard to achieve NMR spectra on a Bruker (AC) $500 \mathrm{MHz}$ NMR spectrometer. Water HRMS model XEVO-G2QTOF\#YCA351 spectrometer was used to record ESI mass spectra. Both tests were performed at room temperature. The melting point was measured in an open-mouth capillary using a hot-plate melting point apparatus.

\section{Synthetic procedures and formulation of the probe}

The chemosensor was made by combining N1(Phenyl(pyridine-2-yl)methyl)benzene-1, 2-diamine (0.273 g, $1.0 \mathrm{mmol})$, and 2-hydroxy-1-naphthaldehyde $(0.172 \mathrm{~g}, 1.0 \mathrm{mmol})$ in $\mathrm{MeOH}(15 \mathrm{~mL})$ under stirring for 12 hours at room temperature to produce the probe 1-(1-(Phenyl(pyridine-2-yl)methyl)benznaphthaldehyde2-ol(1H-benzo[d]imidazole-2-yl)naphthaldehyde-2-ol. The solvent was extracted after ensuring that there was no additional amine and enabling the $\mathrm{MeOH}$ solution of the probe to slowly evaporate. The crude substance was eventually filtered using paper chromatography, yielding needle-shaped red crystals. Mass spectrometry revealed a molecular ion peak that is higher than the predicted one. However, the simplest explanation is to consider the complication of the solvent, acetonitrile $\left(\mathrm{CH}_{3} \mathrm{CN}\right)$, with these $\mathrm{Al}^{3+}$ ions.

\section{Synthesis of aluminum-complex}

The $\mathrm{Al}^{3+}$ complex of the chemosensor was made by combining a refluxing $\mathrm{MeOH}(10 \mathrm{~mL})$ solution of
$\mathrm{Al}\left(\mathrm{NO}_{3}\right) 3.9 \mathrm{H}_{2} \mathrm{O}(0.375 \mathrm{~g}, 1 \mathrm{mmol})$ with a $\mathrm{MeOH}(10$ $\mathrm{mL}$ ) solution of the chemosensor ( $1 \mathrm{mmol}, 0.427 \mathrm{~g})$, and stirring the mixture for 12 hours to produce an orange solution. The solvent was extracted from the solution after allowing it to evaporate. The result was an orange-colored rigid mass.

\section{Spectroscopic studies}

A general method for UV-VIS and fluorescence studies

The probe $(2.14 \mathrm{mg}, 0.001 \mathrm{mmol}$ ) was soluble in $\mathrm{MeOH}$ $(5 \mathrm{~mL})$ and $100 \mu \mathrm{L}$ of $\mathrm{HL}$ solution was diluted with 2 $\mathrm{ml} \mathrm{MeOH}-\mathrm{H}_{2} \mathrm{O}(\mathrm{v} / \mathrm{v} \mathrm{1:4)}$ to give a cumulative volume of $2.1 \mathrm{~mL}$. In water $10 \mathrm{~mL}$ of $\mathrm{Al}\left(\mathrm{NO}_{3}\right)_{3} .9 \mathrm{H}_{2} \mathrm{O}(3.75 \mathrm{mg}$, $0.001 \mathrm{mmol})$ was dissolved. The $\mathrm{Al}^{3+}$ solution $(100 \mu \mathrm{L})$ was added to the HL solution predefined sequence. This sample solution preparation technique may also be used with other cations. At room temperature, the spectra were registered after mixing. The excitation wavelength for the fluorescence sample was $400 \mathrm{~nm}$ (excitation slit $=10.0$ and emission slit $=7.0$ ).

Calculation of the chemosensor's fluorescence quantum yield $(\Phi)$ before and after the $\mathrm{Al}^{3+}$ complication

The following equation was used to calculate the fluorescence quantum yield of the chemosensor and the metal-complex (37).

$\Phi_{\text {sample }}=\left(\mathrm{OD}_{\text {std }} \times \mathrm{A}_{\text {sample }}\right) /\left(\mathrm{OD}_{\text {sample }} \times \mathrm{A}_{\text {std }}\right) \times \Phi_{\text {std }}$

Where, $A_{\text {sample }}$ and $A_{\text {std }}$ represent the areas under the fluorescence spectral curves of the sample and standard sample.

And $O D_{\text {sample }}$ and $O D_{\text {std }}$ are the optical densities of the sample and standard designated at the excitation wavelength.

Acidic quinine sulfate was taken as the standard (Фstd $=0.54$ ) for the quantum yield calculation of ligand and $\mathrm{Al}$ complex.

\section{Live cell imaging \\ Cell line culture}

Cell line from a human liver cancer patient from the National Center for Cell Science (NCCS) in Pune, India, provided Hep G2 and human lung fibroblast cells, WI38. The cells were developed at $37^{\circ} \mathrm{C}$ and $5 \% \mathrm{CO}_{2}$ in DMEM with $10 \%$ FBS (fetal bovine serum), penicillin/ streptomycin (100 units/mL), and penicillin/streptomycin (100 units $/ \mathrm{mL}$ ). All of the treatments were carried out at $37^{\circ} \mathrm{C}$ with a cell density allowed for exponential development (38).

\section{Cell imaging}

Hep G2 cells were cultured on coverslips for 24 hours. After that, the cells were either mock-treated or treated with $5 \mu \mathrm{M}$ ligand and $10 \mathrm{M} \mathrm{Al}^{3+}$ salt for 24 hours at $37^{\circ} \mathrm{C}$. 
Before being viewed under a fluorescence microscope, the cells were rinsed in $1 \times$ PBS and put on a glass slide (Leica). Cell survivability assay

The probe's cell survival was investigated in human lung fibroblast cells, WI38, using a technique described by Samui et al (39). In a nutshell, the MTT test was used to determine the vitality of WI38 cells following exposure to various doses of ligand. The cells were seeded at $10^{4}$ cells per well in 96-well plates and subjected to the probe at concentrations of $0,20,40,60,80$, and $100 \mu \mathrm{M}$ for 24 hours. After treatment, cells were washed twice with 1PBS and incubated for $3-4$ hours at $37^{\circ} \mathrm{C}$ with MTT solution $(450 \mu \mathrm{g} / \mathrm{mL})$. After dissolving the formazan crystals in MTT solubilization solution, the solution was read at 570 $\mathrm{nm}$ with a spectrophotometer (BioTek) and matched to control cells.

\section{Synthesis of aluminum-complex}

Micro analytical data

The $\mathrm{Al}^{3+}$ complex of the chemosensor was generated by combining a $\mathrm{MeOH}(10 \mathrm{~mL})$ solution of the chemosensor (1 mmol, $0.427 \mathrm{~g}$ ) with a refluxing $\mathrm{MeOH}(10 \mathrm{~mL})$ solution of $\mathrm{Al}\left(\mathrm{NO}_{3}\right)_{3} .9 \mathrm{H}_{2} \mathrm{O}(0.375 \mathrm{~g}, 1 \mathrm{mmol})$ and stirring for 12 hours to produce an orange solution. The substance was permitted to evaporate, and the solvent was separated from the solution as a result of the evaporation. Finally, a strong mass of orange pigment was collected.

\section{Spectroscopic studies}

A broad approach to UV-VIS and fluorescence research $\mathrm{Al}^{3+}$ complex of the chemosensor was generated by combining a $\mathrm{MeOH}(10 \mathrm{~mL})$ solution of the chemosensor $(1 \mathrm{mmol}, 0.427 \mathrm{~g})$ with a refluxing $\mathrm{MeOH}(10 \mathrm{~mL})$ solution of $\mathrm{Al}\left(\mathrm{NO}_{3}\right)_{3} \cdot 9 \mathrm{H}_{2} \mathrm{O}(0.375 \mathrm{~g}, 0.001 \mathrm{mmol})$ and whole mixture was stirred for 12 hours to produce an orange solution. The substance was permitted to evaporate, and the solvent was separated from the solution as a result of the evaporation. Finally, a strong mass of orange pigment was collected.

\section{Results}

\section{The probe's synthesis and formulation}

The condensation of $\mathrm{N}^{1}$-(Phenyl (pyridine-2-yl) methyl) benzene-1,2-diamine and 2-hydroxy-1-naphthaldehyde generated 1-(1-(Phenyl(pyridine-2-yl)methyl)benzene1,2-diamine-1H-benzo[d]imidazol-2-yl) naphthalene-2ol with a strong yield of $84 \%$ and a melting point of $190^{\circ} \mathrm{C}$. It was characterized by spectroscopic measurements. The determined molecular weight of 428.1685 and the molecular ion peak of $(\mathrm{HL}+\mathrm{H})^{+}$endorse the molecular identification. The weak bands at 3360 and $3070 \mathrm{~cm}^{-1}$ belong to $v$ (phenolic- $\mathrm{OH})$ and $v(-\mathrm{NH})$, respectively. $v(-$ $\mathrm{CH}=\mathrm{N}-)$ stretching is associated with strong stretches at $1620 \mathrm{~cm}^{-1}$. The singlet at $15.12 \mathrm{ppm}$ correlates to $\delta$ (phenolic-OH); benzylic- $\mathrm{H}(\mathrm{CH}-\mathrm{N})$ at $9.73 \mathrm{ppm}$ in the
1H NMR range of HL (500 MHz, DMSO-d $)$. At 5.90-8.64 $\mathrm{ppm}$, other aromatic protons may be found.

\section{Measured and experimentally micro analytical data}

The measured and experimentally defined values for the probe $\left(\mathrm{C}_{29} \mathrm{H}_{21} \mathrm{~N}_{3} \mathrm{O}\right)$ were $\mathrm{C}, 81.48$ (81.11) percent; $\mathrm{H}, 4.95$ (5.05) percent; and $\mathrm{N}, 9.83$ (9.81) percent, respectively. 1H NMR (500 MHz, DMSO-d $): 15.12$ (s, 1H, OH), 9.73 (s, 1H, benzylic-H), 5.90-8.64 (aromatic-H), IR: 3360 $\mathrm{cm}^{-1}$ (Phenolic-OH), $3070 \mathrm{~cm}^{-1}(-\mathrm{NH})$. No doubt this is $\mathrm{N}-\mathrm{H}$ because Nitrogen has quadrupole moment and that would give rise to broadening, $1620 \mathrm{~cm}^{-1}$ (imine $\mathrm{CH}=\mathrm{N}-$ ). ESI-MS shows Molecular peak at 428.1641 for $[\mathrm{HL}+\mathrm{H}]^{+}$(Mol.wt.(calculated), 428.1685) and at 450.0438 for $[\mathrm{HL}+\mathrm{Na}]^{+}($Mol.wt. Calculated $=450.17)$.

\section{Diffractive X-ray structure of the probe}

Table 1 shows the monoclinic system of space group $\mathrm{P}$ $21 / \mathrm{c}$ for the red X-ray diffraction.

Table 1 shows the ligand's crystallographic information as well as structure refinement parameters. It also shows the acyclic structure of the probe. The reaction of HL with $\mathrm{Al}\left(\mathrm{NO}_{3}\right)_{3} \cdot 9 \mathrm{H}_{2} \mathrm{O}$ in methanol produced $\left[\mathrm{AlL}\left(\mathrm{CH}_{3} \mathrm{CN}\right)\right]^{2+}$, a mononuclear Al-complex. The complex has no large peaks at $3360 \mathrm{~cm}^{-1}$ and $3070 \mathrm{~cm}^{-1}$, indicating the absence of $-\mathrm{OH}$ and $-\mathrm{NH}$ stretching, and $\left(-\mathrm{CH}=\mathrm{N}^{-}\right)$at $1625 \mathrm{~cm}^{-1}$, indicating a higher energy than HL. A molecular ion peak at 495.16 is visible in the mass spectrum, which could be the result of $\mathrm{AlL}\left(\mathrm{CH}_{3} \mathrm{CN}\right)+\mathrm{H}^{+}$. During synthesis, the absence of (phenolic-OH) and $-\mathrm{NH}$ facilitates probe

\begin{tabular}{|c|c|}
\hline Formula & HL (ligand) \\
\hline Empirical formula & $\mathrm{C}_{29} \mathrm{H}_{21} \mathrm{~N}_{3} \mathrm{O}$ \\
\hline Formula weight & 429.50 \\
\hline Crystal System & Monoclinic \\
\hline Space group & $\mathrm{P} 2{ }_{1} / \mathrm{c}$ \\
\hline a $(\AA)$ & $22.180(3)$ \\
\hline$b(\AA)$ & $5.9098(7)$ \\
\hline$c(\AA)$ & $16.938(2)$ \\
\hline $\mathrm{\alpha}=\mathrm{y} /{ }^{\circ}$ & 90 \\
\hline$\beta /^{\circ}$ & $94.383(4)$ \\
\hline$V(\AA)^{3}$ & $2213.7(5)$ \\
\hline Z & 4 \\
\hline $\mathrm{Dc} / \mathrm{g} \mathrm{cm}^{-3}$ & 1.289 \\
\hline$\mu / \mathrm{mm}^{-1}$ & 0.079 \\
\hline$\lambda(\AA)$ & 0.71073 \\
\hline Data $[/>2 \sigma(I)] /$ parameter & $3882 / 299$ \\
\hline $\mathrm{GOF}^{\mathrm{c}}$ & 1.138 \\
\hline Final R indices $[I>2 \sigma(I)]^{a, b}$ & $R_{1}=0.0913, w R_{2}=0.1730$ \\
\hline
\end{tabular}


ionization and $\mathrm{Al}^{3+}$ binding.

\section{Synthesis of Al-complex}

Micro analytical data of the $A l^{3+}$ complex

Figure 3 shows the micro analytical data of the $\mathrm{Al}^{3+}$ complex $\left(\mathrm{C}_{31} \mathrm{H}_{23} \mathrm{AlN}_{4} \mathrm{O}_{1}\right)$ with calculated values (\%) of $\mathrm{C}, 75.29 ; \mathrm{H}$, 4.69; N, 11.33; IR: $1625 \mathrm{~cm}^{-1}$ (imine -CH=N-). For [AlL $\left.\left(\mathrm{CH}_{3} \mathrm{CN}\right)\right]^{2+}+\mathrm{H}^{+}, \mathrm{M}$, the mass spectrum reveals a strong peak at 495.19 and showed the weight of 495.16 .

\section{UV-VIS spectroscopy experiments}

At $25^{\circ} \mathrm{C}$, spectrophotometric titrations of $\mathrm{HL}$ in $1: 4$ $\mathrm{MeOH} / \mathrm{H}_{2} \mathrm{O}(\mathrm{v} / \mathrm{v})$ with progressive additions of $\mathrm{Al}^{3+}$ were used to explore the interaction of $\mathrm{HL}$ with $\mathrm{Al}^{3+}$. The probe's absorption maxima are initially $428 \mathrm{~nm}$, but after association with the $\mathrm{Al}^{+3}$ ion, the absorbance increases with a slight red shift of the maximum to $438 \mathrm{~nm}$ (Figure 1), demonstrating that the reaction is clean and uncomplicated. Intramolecular charge transfer through chelation is responsible for the red-shifting of the HL bands generated by $\mathrm{Al}^{3+}$ inclusion. The increase in absorbance is linear until the molar ratio of $\left[\mathrm{Al}^{3+}\right]:[\mathrm{HL}]$ reaches $1: 1$, at which it becomes non-variable as $\left[\mathrm{Al}^{3+}\right]$ increases. It indicates that $\mathrm{HL}$ and $\mathrm{Al}^{3+}$ have a stoichiometry of $1: 1$. The job plot was created by scheming the absorbance versus various mole fractions of $\mathrm{Al}^{3+}$ while keeping the volume of the solution constant, and the molar fraction maxima were achieved at roughly 0.5 -mole fraction, which supported 1:1 complex formation of $\mathrm{HL}$ and $\mathrm{Al}^{3+}$.

\section{Fluorescence sensing for $\mathrm{Al}^{3+}$}

The fluorescence quantum yield was estimated using quinine sulfate as a reference and a standard of $\mathrm{MeOH} /$ $\mathrm{H}_{2} \mathrm{O}$ (v/v 1:4) with a known quantum yield of $\mathrm{R}=0.54$ (40). When the probe was excited at $400 \mathrm{~nm}$, no emission was recorded. The ligand and quinine sulfate $\left(\mathrm{C}_{40} \mathrm{H}_{50} \mathrm{~N}_{4} \mathrm{O}_{8} \mathrm{~S}\right)$ were stimulated at the same wavelength $(502 \mathrm{~nm})$, and their absorbance was almost identical. As a result, the ligand's quantum yield ( $\left.\Phi_{\text {ligand }}\right)$ was 0.0186 , and following chelation with $\mathrm{Al}^{3+}$, the high-intensity emission band at $502 \mathrm{~nm}$ was detected. As a consequence, the calculated quantum yield for the $\mathrm{Al}^{3+}$-complex is 0.2748 . As a consequence of the metal complication, the fluorescence quantum yield raised.

As a result of the metal complication, the fluorescence quantum yield increases. Other cations $\left(\mathrm{Na}^{+}, \mathrm{K}^{+}, \mathrm{Ca}^{2+}\right.$, $\mathrm{Mg}^{2+}, \mathrm{Mn}^{2+}, \mathrm{Fe}^{3+}, \mathrm{Zn}^{2+}, \mathrm{Co}^{2+}, \mathrm{Ni}^{2+}, \mathrm{Pd}^{2+}, \mathrm{Cd}^{2+}, \mathrm{Hg}^{2+}$, $\mathrm{Cu}^{2+}, \mathrm{Ba}^{2+}$, and $\mathrm{Pb}^{2+}$ ) have negligible fluorescence emission in $\mathrm{MeOH} / \mathrm{H}_{2} \mathrm{O}$ ( $\mathrm{v} / \mathrm{v}$ 1:4). As a consequence, under comparable experimental settings, the probe preferentially shows "turn on" $\mathrm{Al}^{3+}$ emission (Figure 2). The fluorescence intensity increases with the constant addition of $\mathrm{Al}^{3+}$ to the probe solution until it reaches a 1:1 molar ratio, at which point it becomes saturated. When $\mathrm{Al}^{3+}$ is abundantly added to the mixture, the rate of emission does not change (Figure 3).

Drawing of job plot by fluorescence spectroscopy method The increase in fluorescence strength for $\mathrm{HL}+\mathrm{Al}^{3+}$ may be attributed to the reduction of ESIPT in free HL and the chelation enhancement effect induced by the coordination of the ligand's - $\mathrm{O}$ and - $\mathrm{N}$ donor sites with the metal ion.

The binding constant value of $\mathrm{Al}^{3+}$ with the probe was measured using the modified Benesi-Hildebrand equation, $1 / \Delta \mathrm{F}=1 / \Delta \mathrm{F}_{\max }+(1 / \mathrm{K}[\mathrm{C}])\left(1 / \Delta \mathrm{F}_{\max }\right) . \Delta \mathrm{F}=$ $\mathrm{F}_{-} \mathrm{F}_{0}$ and $\Delta \mathrm{F}_{\text {max }}=\mathrm{F}_{\text {max }}-\mathrm{F}_{0}$, where $F_{0}, F$, and $F_{\text {max }}$ are the fluorescence emission intensities of the probe in the absence of $\mathrm{Al}^{+3}$, at an intermediate $\mathrm{Al}^{3+}$ concentration, and at a concentration of total saturation, respectively, where $K$ is the binding constant and $[C]$ is the $\mathrm{Al}^{3+}$ concentration. The slope of the plot of $\left(\mathrm{F}_{\max }-\mathrm{F} 0\right) /\left(\mathrm{F}-\mathrm{F}_{0}\right)$ against $[\mathrm{C}]^{-1}$ for the probe was used to calculate the value of $\mathrm{K}$.

To obtain a deeper understanding of the complexation reaction, a fluorometric titration was conducted, and the relationship $\left[\left(\mathrm{F}_{\max }-\mathrm{F}_{0}\right) /\left(\mathrm{F}-\mathrm{F}_{0}\right)\right]$ versus $1 /\left[\mathrm{Al}^{+3}\right]$ was plotted using the Benesi-Hildebrand equation (Figure 4), and the

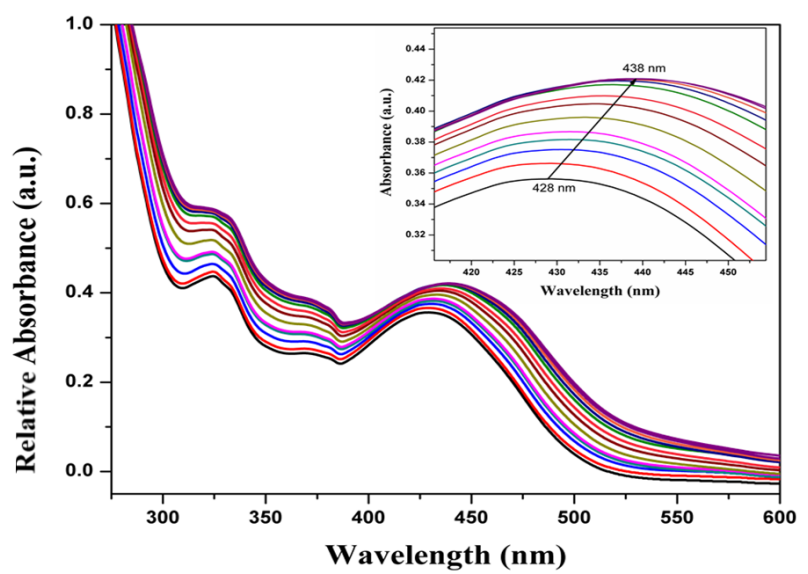

Figure 1. Change in $\mathrm{HL}(50 \mu \mathrm{M})$ absorption spectrum with gradual addition of $\mathrm{Al}^{3+}$ ions $\left(5 \mu \mathrm{M}\right.$ each) in $\mathrm{MeOH} / \mathrm{H}_{2} \mathrm{O}(\mathrm{v} / \mathrm{v} 1: 4)$; inset: zoom picture at wavelength of $415-455 \mathrm{~nm}$.

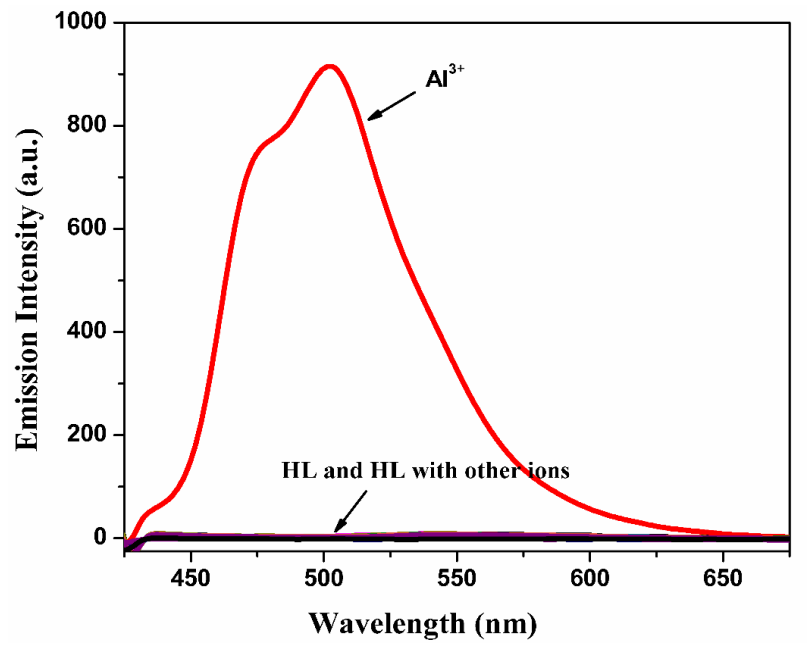

Figure 2. Change in emission spectrum of $\mathrm{HL}(50 \mu \mathrm{M})$ upon gradual addition of different metal ions $\left(100 \mu \mathrm{M}\right.$ each) in $\mathrm{MeOH} / \mathrm{H}_{2} \mathrm{O}(\mathrm{v} / \mathrm{v} 1: 4)$. 


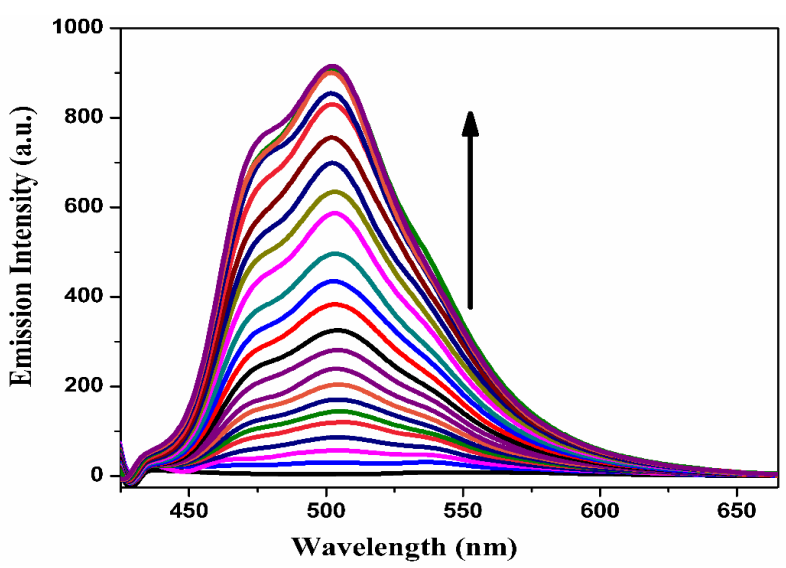

Figure 3. Changes in the emission range of $\mathrm{HL}(50 \mu \mathrm{M})$ varies when $\mathrm{Al}^{3+}$ ions (5 $\mu \mathrm{M}$ each) are progressively introduced to $\mathrm{MeOH} / \mathrm{H}_{2} \mathrm{O}(\mathrm{v} / \mathrm{v} 1: 4)$.

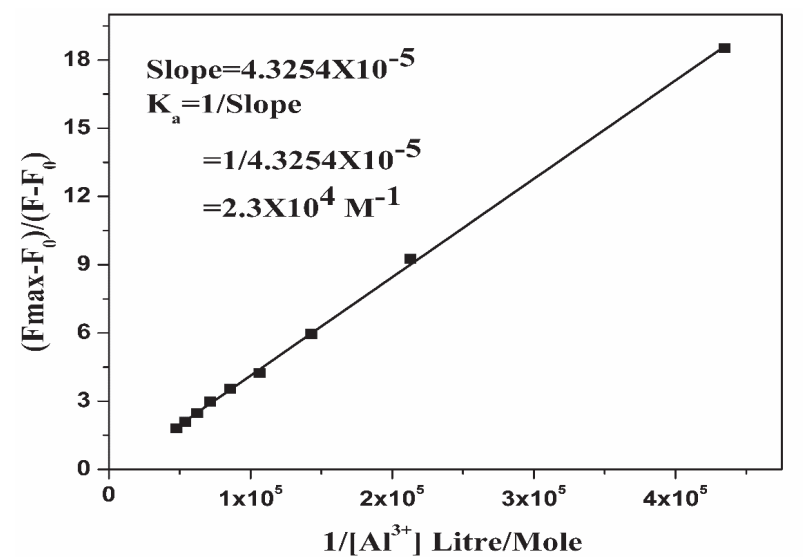

Figure 4. Benesi-Hildebrand plot of $\{(\mathrm{Fmax}-\mathrm{Fo}) /(\mathrm{F}-\mathrm{Fo})\}$ vs. $1 /\left[\mathrm{Al}^{+3}\right]$ by fluorescence spectroscopy-fluorescence titration curve of the ligand with $\mathrm{Al}^{+3}$.

interaction constant $\left(\mathrm{K}_{\mathrm{a}}\right)$ calculated by the fluorescence titration method for ligand with $\mathrm{Al}^{3+}$ was found to be $2.310^{4}$ $\mathrm{M}^{-1}$. Following the $3 \sigma$ process, the maximum of detection of $\mathrm{Al}^{3+}$ was determined to be $3.3 \mathrm{nM}$.

The effect of $\mathrm{pH}$ on the fluorescence strength of HL and the $\mathrm{HL}-\mathrm{Al}^{3+}$ complex was investigated; it was discovered that HL emits no significant fluorescence in the $\mathrm{pH}$ ranges of 2 to 12 , and that the ligand emits in $\mathrm{pH}$ ranges of 6.0 to 12 when $\mathrm{Al}^{3+}$ is present, as shown in Figure 5. In the $\mathrm{pH}$ range of $2-12$, the probe is stable, with a maximal turn-on response to $\mathrm{Al}^{3+}$ at $\mathrm{pH}$ 6. The intensity of the emission drops sharply at $\mathrm{pH} 7$, which might be due to the combination of bases with a metal ion $\left(\mathrm{Al}^{3+}\right)$, which reduces the ligandmetal interaction. This means that the HL will detect $\mathrm{Al}^{3+}$ in biological $\mathrm{pH}$ at far lower quantities than the WHO recommended value $(7.41 \mathrm{mM})$ in drinking water.

For the detection of $\mathrm{Al}^{3+}$, intervention on fluorescence by various citations has been studied. Figure 6 shows that no significant interference is observed.

Fluorescence lifespan estimates were used to estimate the reliability of the stimulated probe and its $\mathrm{Al}$ complex. Figure 7 exhibits bi-exponential ( $\left.{ }_{\mathrm{av}}=0.3290 \mathrm{~ns}\right)$ and monoexponential ( $\tau=3.4637 \mathrm{~ns}$ ) fluorescence decay profiles for

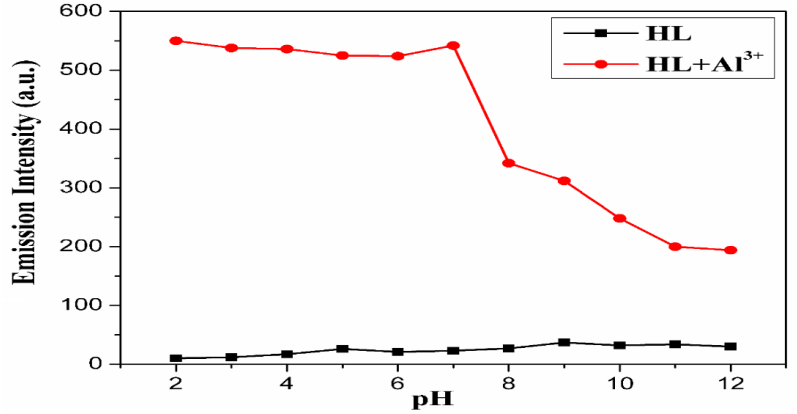

Figure 5. Fluorescence intensity of the receptor $\mathrm{HL}$ and the HL$\mathrm{Al}^{3+}$ combination as a function of $\mathrm{pH}$.

the ligand and its Al complex, respectively. The longer lifespan of the complex for ligand might be due to the increased stability of the complex in an excited state.

Here, the sensitivity of highly emissive $\mathrm{Al}$ complex with different anions like $\mathrm{S}_{2} \mathrm{O}_{3}^{2-}, \mathrm{SCN}^{-}, \mathrm{PO}_{4}^{3-}, \mathrm{H}_{2} \mathrm{PO}_{4}^{-}, \mathrm{HPO}_{4}^{2-}$ , I- $\mathrm{OAc}^{-}, \mathrm{ClO}_{4}^{-}, \mathrm{SO}_{4}^{2-}, \mathrm{HSO}_{4}^{-}, \mathrm{Cl}^{-}, \mathrm{F}^{-}, \mathrm{HF}_{2}^{-}, \mathrm{NO}_{3}^{-}, \mathrm{Br}^{-}$, $\mathrm{NO}_{2}^{-}, \mathrm{CN}^{-}, \mathrm{N}_{3}^{-}, \mathrm{AsO}_{4}^{3-}$, and $\mathrm{AsO}_{2}^{-}$was checked, and it was found that some of the anions $\left(\mathrm{PO}_{4}^{3-}, \mathrm{H}_{2} \mathrm{PO}_{4}^{-}, \mathrm{HPO}_{4}^{2-}, \mathrm{F}^{-}\right.$, and $\mathrm{HF}_{2}^{-}$) quench the emission i.e., it is not specific for a single anion, as shown in Figure 8.

\section{Detection of $\mathrm{Al}^{3+}$ ion in industrial wastewater}

The industrial waste water $(200 \mathrm{~m} »)$ by the direct application in chemosensor for the detection of $\mathrm{Al}^{+3}$ ion was studied. The fluorescence concentration is calculated

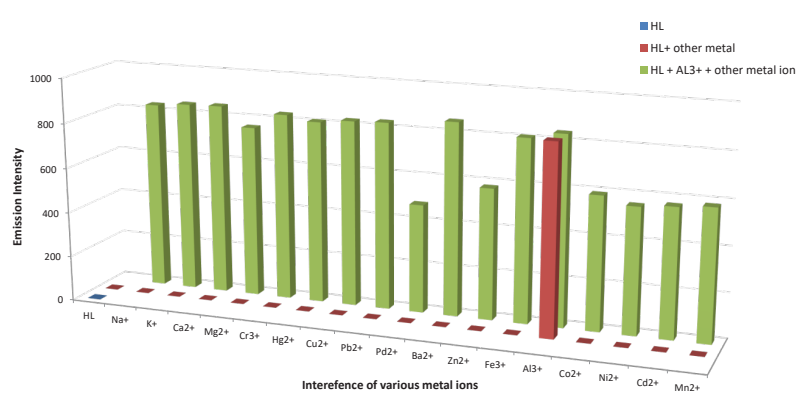

Figure 6. Interference of other metal ions towards $\mathrm{Al}^{3+}{ }^{3+}$ ion sensitivity.

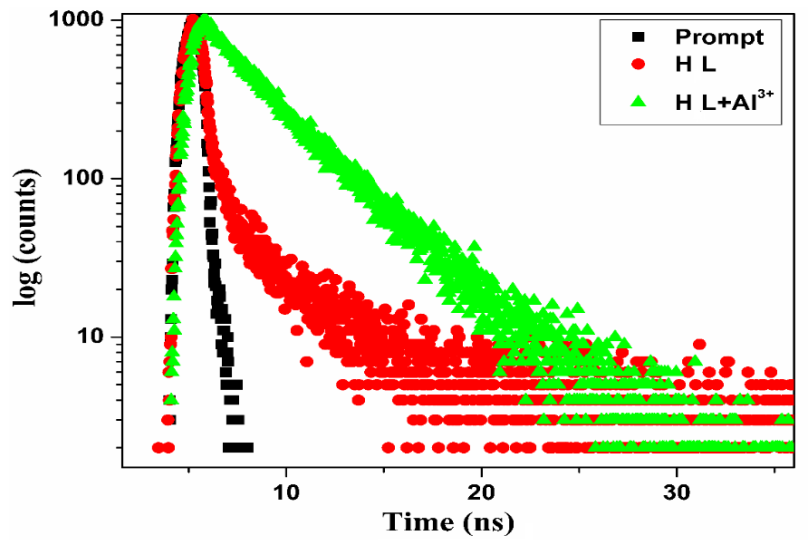

Figure 7. Fluorescence lifetime plot of the probe and $\mathrm{Al}$ complex in $\mathrm{MeOH} /$ $\mathrm{H}_{2} \mathrm{O}(\mathrm{v} / \mathrm{v} 1: 4)$. 


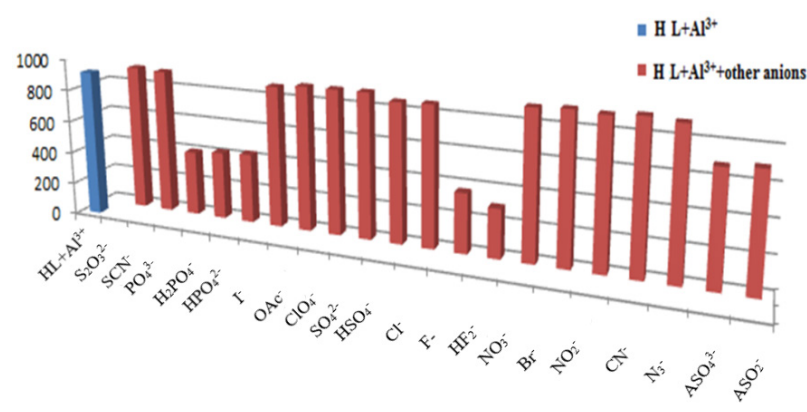

Figure 8. Change in emission intensity of the emissive Al-complex with different anions.

at $502 \mathrm{~nm}$ emission on excitation at $400 \mathrm{~nm}$ to produce a calculation plot by volume of analyte $\left(\mathrm{Al}^{3+}\right)$ and emission intensity (a.u.) in a $1: 4 \mathrm{MeOH} / \mathrm{H}_{2} \mathrm{O}(\mathrm{v} / \mathrm{v})$ medium. The wastewater samples $(200 \mathrm{~mL})$ were collected from the pharmaceutical sector in Kolkata, West Bengal, India, in a clean and PVC container. The calibration plot was used to determine the unknown quantity of $\mathrm{Al}^{3+}$ in the collected wastewater sample, and the quantity of $\mathrm{Al}^{3+}$ is presented in Table 2.

The emission intensity changes linearly as the concentration of $\mathrm{Al}^{3+}$ ion-containing effluent increases, and no regression was performed.

\section{Living cell imaging}

Cell survivability assay to determine its biocompatibility

The probe in vitro cytotoxicity was assessed on the WI-38 cell line to determine its biocompatibility. The MTT test was done after the cells were treated for 24 hours with five different doses of ligand $(20,40,60,80$, and $100 \mu \mathrm{M})$. At a maximum concentration of $100 \mu \mathrm{M}$, the ligand showed no significant toxicity. As a result, the ligand is biocompatible and suited for biological applications.

\section{Fluorescence microscopic examination of cell imaging}

The fluorescence microscopic examination was carried out to visualize the cellular absorption of the probe $(5 \mu \mathrm{M})$ and $\mathrm{Al}^{3+}$ salts $(10 \mu \mathrm{M})$. Under the microscope, a clear blue fluorescent light could be detected. Based on this finding, it can be deduced that the cells readily absorb the probe and the $\mathrm{Al}^{3+}$ salts, resulting in a blue fluorescent signal. As a result, the probe was successfully used to identify intracellular $\mathrm{Al}^{3+}$ in $\mathrm{HePG} 2$.

\section{Discussion}

Pharmaceuticals $\mathrm{Al}$ has been tested and developed as a fluorogenic sensor for $\mathrm{Al}^{3+}$ ions, which have been identified as a possible food and drinking water pollutant.
The detection of $\mathrm{Al}^{3+}$ ions is very important because it can cause human liver cancer and human lung fibroblast. The main aim of the study was to design a fluorescent chemosensor (41) and investigate detection trace $\mathrm{Al}^{+3}$ ions from pharmaceutical wastewater. The molecular ion peak of $(\mathrm{HL}+\mathrm{H})+$ was 428.1641 and the calculated molecular weight was $428.1685 \mathrm{~g} / \mathrm{mol}$, which supports the molecular identity. The weak band at 3360 and $3070 \mathrm{~cm}^{-1}$ refer to (phenolic-OH) and $(-\mathrm{NH})$, respectively. Strong stretches at $1620 \mathrm{~cm}^{-1}$ are assigned to $(-\mathrm{CH}=\mathrm{N}-)$ stretching. The $1 \mathrm{H}$ NMR spectrum of HL (500 MHz, DMSO-d6) demonstrates singlet at $15.12 \mathrm{ppm}$ corresponds to $\delta$ (phenolic-OH); benzylic-H $(\mathrm{CH}-\mathrm{N})$ at $9.73 \mathrm{ppm}$. Other aromatic protons appear at 5.90-8.64 ppm. The probe has absorption maxima at $428 \mathrm{~nm}$, but upon coordination with $\mathrm{Al}^{3+}$ ion, there is an increase in absorption with a small red shift of the maxima to $438 \mathrm{~nm}$, indicating that the reaction is clean and straightforward. The red-shifting of the bands of HL (ligand) upon $\mathrm{Al}^{3+}$ addition is attributed to an intramolecular charge transfer through the chelation. The change of absorbance is linear until the molar ratio $\left[\mathrm{Al}^{3+}\right]:[\mathrm{HL}]$ reaches $1: 1$, as well as no longer changes with an increase in $\left[\mathrm{Al}^{3+}\right]$. It suggests that the stoichiometry between $\mathrm{HL}$ and $\mathrm{Al}^{3+}$ is 1:1. The fluorescence emission of $\mathrm{HL}$ with other cations $\left(\mathrm{Na}^{+}, \mathrm{K}^{+}, \mathrm{Ca}^{2+}, \mathrm{Mg}^{2+}, \mathrm{Mn}^{2+}, \mathrm{Fe}^{3+}\right.$, $\mathrm{Zn}^{2+}, \mathrm{Co}^{2+}, \mathrm{Ni}^{2+}, \mathrm{Pd}^{2+}, \mathrm{Cd}^{2+}, \mathrm{Hg}^{2+}, \mathrm{Cu}^{2+}, \mathrm{Ba}^{2+}$, and $\mathrm{Pb}^{2+}$ ) in $\mathrm{MeOH} / \mathrm{H}_{2} \mathrm{O}(\mathrm{v} / \mathrm{v}$ 1:4) is insignificant. Thus, the probe is selectively showing "turn on" emission to $\mathrm{Al}^{3+}$ under the identical experimental condition. The probe is stable in the $\mathrm{pH}$ range of $2-12$, and the maximum turn-on response to $\mathrm{Al}^{3+}$ was observed at $\mathrm{pH}$ 6. At $\mathrm{pH} \mathrm{7,} \mathrm{there}$ was a sudden decrease in emission intensity; this might be due to the interaction of bases with a metal ion $\left(\mathrm{Al}^{3+}\right)$ and lower the ligand-metal interaction. This indicates that the HL is useful for the detection of $\mathrm{Al}^{3+}$ at the biological $\mathrm{pH}$ at a much lower concentration than that of the WHO recommended value $(7.41 \mathrm{mM})$ in drinking water. For binding stoichiometry of $\mathrm{HL}$ and $\mathrm{Al}^{3+}$, the molar fraction maxima were obtained at around 0.5 mole fraction, which indeed supports 1:1 complex formation of $\mathrm{HL}$ and $\mathrm{Al}^{3+}$. The ligand exhibited no significant toxicities even at the highest concentration of $100 \mu \mathrm{M}$. Therefore, the ligand is good biocompatible and is beneficial for biological applications.

\section{Conclusion}

The condensation reaction of $\mathrm{N}^{1}$-(Phenyl(pyridine2-yl)methyl)benzene-1,2-diamine $(0.273 \mathrm{~g}, 1.0 \mathrm{mmol})$ and 2-hydroxy-1-naphthaldehyde $(0.172 \mathrm{~g}, 1.0 \mathrm{mmol})$ in $\mathrm{MeOH}(15 \mathrm{ml})$ for 12 hours at room temperature

Table 2. Estimation of the amount of $\mathrm{Al}^{3+}$ ions in industrial wastewater using $\mathrm{HL}$

\begin{tabular}{|c|c|c|c|c|c|c|}
\hline Sample & S. No. & $\begin{array}{c}\text { Emission } \\
\text { Intensity at } 502 \\
\text { nm (a.u.) }\end{array}$ & $\begin{array}{c}\text { The Concentration of } \\
\text { Reference Required (mM) }\end{array}$ & $\begin{array}{l}\text { The Concentration of } \\
\text { Industrial Wastewater } \\
\text { Required (mM) }\end{array}$ & $\begin{array}{c}\text { Ratio of Reference } \\
\text { concentration: Sample } \\
\text { waste water concentration }\end{array}$ & $\begin{array}{c}\text { Amount of } \\
\mathrm{Al}^{3+} \text { ions (mM) }\end{array}$ \\
\hline \multirow{2}{*}{$\begin{array}{l}\text { Industrial } \\
\text { wastewater }\end{array}$} & 1 & 64 & 70.12 & 26.75 & 2.621 & 0.381 \\
\hline & 2 & 45 & 103.73 & 38.65 & 2.683 & 0.372 \\
\hline
\end{tabular}


yielded 1-(1-(Phenyl(pyridine-2-yl)methyl)-1H-benzo[d] imidazol-2-yl)naphthalene-2-ol. When irradiated at 400 $\mathrm{nm}$, the probe was effectively employed as a "turn-on" fluorescence chemosensor to $\mathrm{Al}^{3+}$ ion in the presence of a large number of other metal ions, and displays high strong blue emission $\left(\lambda_{\text {em }}, 502 \mathrm{~nm}\right)$. The probe's limit of detection (LOD) for $\mathrm{Al}^{3+}$ is $3.3 \mathrm{nM}$. Mass spectrum analysis, job plot, and $1 \mathrm{H}$ NMR measurements were used to determine the 1:1 metal-to-ligand complex. The pharmaceutical company effluent contains $0.38 \mathrm{mM}$ of $\mathrm{Al}$ ion concentration at 64 emission intensity, which is significantly less than the WHO standard of $7.41 \mathrm{mM}$. The probe may also be used to detect $\mathrm{Al}^{3+}$ ions in living cells (Hep G2). By fluorescence cell imaging processes, HL becomes a flexible sensor for identifying intracellular $\mathrm{Al}^{3+}$ in human liver cancer cell line Hep G2 and human lung fibroblast cell lines, and the probe's non-toxicity has been validated by MTT test up to $100 \mu \mathrm{M}$. All tests were conducted at ambient temperature.

\section{Future Recommendations}

The following research suggestions were well-received and can be utilized in future studies.

- In order to provide reliable data on the incidence of $\mathrm{Al}$ in industrial effluent, a more complete examination of a number of additional samples from diverse enterprises is necessary.

- Using DFT energy computations of the probe and the metal complex, the crystal structure of the ligand and the complex, including their HOMO-LUMO transitions, must be examined in detail.

- The crystal structure is critical, and it should be fully investigated while considering the metal and ligand coordination efficiency.

- When the chemical shift values of aromatic compounds are close together, it is difficult to distinguish the proton NMR signal peaks. As a result, the proton signal peaks should be widened and more easily distinguishable.

- The solid-state fluorescence experiment must be completed before the probes be used as light emitting diodes.

\section{Acknowledgements}

The authors would like to thank the faculties working in Materials Science and Engineering Department, Jimma University, Jimma, Ethiopia, for providing support to complete the MSc thesis. The authors confirm that no funding was received to conduct this study.

\section{Ethical issues}

The authors certify that this manuscript is the original work of the authors, all data collected during the study are presented in this manuscript, and no data from the study has been or will be published elsewhere separately.

\section{Competing interests}

The authors declare that they have no competing interests.

\section{Authors' contributions}

All authors contributed to the structure, content, and writing of the paper. The final version of the manuscript was reviewed, read, confirmed, and approved by all authors.

\section{References}

1. Berthon G. Aluminum speciation in relation to aluminum bioavailability, metabolism and toxicity. Coord Chem Rev 2002; 228(2): 319-41. doi: 10.1016/S0010-8545(02)00021-8.

2. Panhwar AH, Kazi TG, Afridi HI, Abbasi AR, Arain MB, Arain SA, et al. Ultrasonic-assisted ionic liquid-based microextraction for preconcentration and determination of aluminum in drinking water, blood and urine samples of kidney failure patients: A multivariate study. Analytical Methods 2014; 6(20): 8277-83. doi: 10.1039/C4AY01735H.

3. World Health Organization. Guidelines for drinkingwater quality: volume 1: recommendations, World Health Organization 1993; 2nd ed. Available from: https://apps. who.int/iris/handle/10665/259956

4. Reiber SH, Kukull W, Standish-Lee P. Drinking water aluminum and bioavailability. Journal of the American Water Works Association 1995; 87(5): doi. https://doi. org/10.1002/j.1551-8833.1995.tb06367.x

5. Alfrey AC, LeGendre GR, Kaehny WD. The dialysis encephalopathy syndrome. Possible aluminum intoxication. N Engl J Med 1976; 294(4): 184-8. doi: 10.1056/NEJM197601222940402.

6. Rondeau V, Commenges D, Jacqmin-Gadda H, Dartigues JF. Relation between aluminum concentrations in drinking water and Alzheimer's disease: An 8-year follow-up study. Am J Epidemiol 2000; 152(1): 59-66. doi: 10.1093/ aje/152.1.59.

7. Martyn CN, Coggon DN, Inskip H, Lacey RF, Young WF. Aluminum concentrations in drinking water and risk of Alzheimer's disease. Epidemiology 1997; 8(3): 281-6. doi: 10.1097/00001648-199705000-00009.

8. Miller RG, Kopfler FC, Kelty KC, Stober JA, Ulmer NS. The occurrence of aluminum in drinking water. American Water Works Association 1984; 76(1): 84-91. doi: 10.1002/ j.1551-8833.1984.tb05267.x.

9. Gauthier E, Fortier I, Courchesne F, Pepin P, Mortimer J, Gauvreau D. Aluminum forms in drinking water and risk of Alzheimer's disease. Environ Res 2000; 84(3): 234-46. doi: 10.1006/enrs.2000.4101.

10. Wettstein A, Aeppli J, Gautschi K, Peters M. Failure to find a relationship between mnestic skills of octogenarians and aluminum in drinking water. Int Arch Occup Environ Health 1991; 63(2): 97-103. doi: 10.1007/BF00379071.

11. McLachlan DR, Bergeron C, Smith JE, Boomer D, Rifat SL. Risk for neuropathologically confirmed Alzheimer's disease and residual aluminum in municipal drinking water employing weighted residential histories. Neurology 1996; 46(2): 401-5. doi: 10.1212/wnl.46.2.401.

12. Chen $\mathrm{CH}$, Liao DJ, Wan CF, Wu AT. A turn-on and reversible Schiff base fluorescence sensor for $\mathrm{Al} 3+$ ion. Analyst 2013; 138(9): 2527-30. doi: 10.1039/c3an00004d.

13. Campbell A, Becaria A, Lahiri DK, Sharman K, Bondy SC. Chronic exposure to aluminum in drinking water increases inflammatory parameters selectively in the brain. J Neurosci Res 2004; 75(4): 565-72. doi: 10.1002/jnr.10877.

14. Schintu M, Meloni P, Contu A. Aluminum fractions in drinking water from reservoirs. Ecotoxicology and Environmental Safety 2000; 46(1): 29-33. doi: 10.1006/ eesa.1999.1887. 
15. Akbari H, Soleimani H, Radfard M, Biglari H, Faraji $\mathrm{H}$, Nabavi S, et al. Data on aluminum concentration in drinking water distribution network of rural water supply in Sistan and Baluchistan province, Iran. Data in Brief 2018; 20: 1804-9. doi: 10.1016/j.dib.2018.08.180.

16. Zhang Y, Shi B, Zhao Y, Yan M, Lytle DA, Wang D. Deposition behavior of residual aluminum in drinking water distribution system: Effect of aluminum speciation. Journal of Environmental Sciences 2016; 42: 142-51. doi: 10.1016/j.jes.2015.05.010.

17. Klotz K, Weistenhofer W, Neff F, Hartwig A, van Thriel C, Drexler H. The health effects of aluminum exposure. Dtsch Arztebl Int 2017; 114(39): 653-659. doi: 10.3238/ arztebl.2017.0653.

18. Panhwar AH, Kazi TG, Afridi HI, Arain SA, Arain MS, Brahaman KD, Naeemullah, Arain SS. Correlation of cadmium and aluminum in blood samples of kidney disorder patients with drinking water and tobacco smoking: Related health risk. Environ Geochem Health 2016; 38(1): 265-74. doi: 10.1007/s10653-015-9715-y.

19. Wasana HM, Perera GD, De Gunawardena PS, Bandara J. The impact of aluminum, fluoride, and aluminum-fluoride complexes in drinking water on chronic kidney disease. Environ Sci Pollut Res Int 2015; 22(14): 11001-9. doi: 10.1007/s11356-015-4324-y.

20. Ganvir V, Das K. Removal of fluoride from drinking water using aluminum hydroxide coated rice husk ash. J Hazard Mater 2011; 185(2-3): 1287-94. doi: 10.1016/j. jhazmat.2010.10.044.

21. Van Dyke N, Yenugadhati N, Birkett NJ, Lindsay J, Turner MC, Willhite CC, Krewski D. Association between aluminum in drinking water and incident Alzheimer's disease in the Canadian Study of Health and Aging cohort. Neurotoxicology 2021; 83: 157-165. doi: 10.1016/j. neuro.2020.04.002.

22. Wang W, Yang H, Wang X, Jiang J, Zhu W. Factors effecting aluminum speciation in drinking water by laboratory research. J Environ Sci (China) 2010; 22(1): 47-55. doi: 10.1016/s1001-0742(09)60073-5.

23. Kimura M, Matsui Y, Kondo K, Ishikawa TB, Matsushita T, Shirasaki N. Minimizing residual aluminum concentration in treated water by tailoring properties of polyaluminum coagulants. Water Research 2013; 47(6): 2075-84. doi: 10.1016/j.watres.2013.01.037.

24. Willhite CC, Ball GL, McLellan CJ. Total allowable concentrations of monomeric inorganic aluminum and hydrated aluminum silicates in drinking water. Crit Rev Toxicol 2012; 42(5): 358-442. doi: 10.3109/10408444.2012.674101.

25. Becaria A, Campbell A, Bondy SC. Aluminum as a toxicant. Toxicol Ind Health 2002; 18(7): 309-20. doi: 10.1191/0748233702th157oa.

26. Pharmaceutical industry analysis report. Korea Health Industry Development Institute. Chungbuk. 2016; 5-41. [Cited 2017] Available from: https://scholar.google.com/ scholar_lookup?title $=$ Pharmaceutical + Industry + Analysis + Report.\&publication_year $=2017$

27. Son HJ, Jang SH. Occurrence of residual pharmaceuticals and fate, residue and toxic effect in drinking water resources. J Korean Soc Environ Eng 2011; 33(6): 453-479. doi: 10.4491/KSEE.2011.33.6.453.

28. Heberer T. Occurrence, fate, and removal of pharmaceutical residues in the aquatic environment: A review of recent research data. Toxicol Lett 2002; 131(1-2): 5-17. doi: 10.1016/s0378-4274(02)00041-3.
29. Fent K, Weston AA, Caminada D. Ecotoxicology of human pharmaceuticals. Aquat Toxicol 2006; 76(2): 122-59. doi: 10.1016/j.aquatox.2005.09.009.

30. Korea Pharmaceutical Industry Guide. Korea Pharmaceutical and Bio-Pharma Manufacturers Association. 2017; 125-138. [Cited 2017]. Available from: https://www.kpbma.or.kr/english/globalization

31. Malakootian M, Pournamdari M, Asadipour A, Mahdizadeh H. Degradation and removal of p-nitroaniline from aqueous solutions using a novel semi-fluid Fe/charcoal micro-electrolysis reactor. Korean J Chem Eng 2019; 36(2): 217-25. doi: 10.1007/s11814-018-0166-x.

32. Khodadadi M, Mesdaghinia A, Nasseri S, Ghaneian MT, Ehrampoush MH, Hadi M. Prediction of the waste stabilization pond performance using linear multiple regression and multilayer perceptron neural network: A case study of Birjand, Iran. Environmental Health Engineering and Management Journal 2016; 3(2): 81-9. doi: 10.15171/EHEM.2016.05.

33. Barbooti MM. Role of organic matter, clay, and iron contents in the sorption of oxytetracycline on river sediments. Environ Health Eng Manag 2017; 4(2): 109-15. doi: 10.15171/EHEM.2017.15.

34. Malakootian M, Mahdizadeh $H$, Khavari M, Nasiri A, Gharaghani MA, Khatami M, Sahle-Demessie E, Varma RS. Efficiency of novel Fe/charcoal/ultrasonic micro-electrolysis strategy in the removal of Acid Red 18 from aqueous solutions. Journal of Environmental Chemical Engineering 2020; 8(2): 103553-7. doi: 10.1016/j. jece.2019.103553.

35. Amirmahani N, Mahdizadeh H, Malakootian M, Pardakhty A, Mahmoodi NO. Evaluating nanoparticles decorated on $\mathrm{Fe}_{3} \mathrm{O}_{4} @ \mathrm{SiO}_{2}$-schiff base $\left(\mathrm{Fe}_{3} \mathrm{O}_{4} @ \mathrm{SiO}_{2}\right.$-APTMS-HBA) in adsorption of ciprofloxacin from aqueous environments. Journal of Inorganic and Organometallic Polymers and Materials 2020; 30: 3540-3551. doi: 10.1007/s10904-02001499-5.

36. Chaudhuri S, Bera S, Biswas MK, Roy AS, Weyhermuller T, Ghosh P. Oxidovanadium (IV), Oxidomolybdenum(VI) and cobalt (III) complexes of o-phenylenediamine derivatives: Oxidative dehydrogenation and photoluminescence. Inorg Chem Front 2014; 1(4): 331-41. doi: 10.1039/C3QI00103B.

37. Maiti D, Islam AS, Sasmal M, Prodhan C, Ali M. Selective sensing of nitric oxide by a 9, 10-phenanthroquinonepyridoxal based fluorophore. Photoch Photobio Sci 2018; 17(9): 1213-21. doi: 10.1039/C8PP00115D.

38. Nakashima Y, Nahar S, Miyagi-Shiohira C, Kinjo T, Kobayashi N, Saitoh I, Watanabe M, Fujita J, Noguchi H. A Liquid Chromatography with Tandem Mass SpectrometryBased Proteomic Analysis of Cells Cultured in DMEM 10\% FBS and Chemically Defined Medium Using Human Adipose-Derived Mesenchymal Stem Cells. Int J Mol Sci 2018; 19(7): 2042. doi: 10.3390/ijms19072042.

39. Samui A, Pal K, Karmakar P, Sahu SK. In situ synthesized lactobionic acid conjugated NMOFs, a smart material for imaging and targeted drug delivery in hepatocellular carcinoma. Mat Sci ENG C 2019; 98: 772-81. doi: 10.1016/j. msec.2019.01.032.

40. Hens A. A turn off and reversible fluorescence probe (HNAPP) for $\mathrm{Zn}$ (II) ion towards inorganic phosphate ions ( $\mathrm{H}_{2} \mathrm{P}$ and $\mathrm{HP}$ ) at physiological pH. RSC Adv 2015; 5(67): 54352-54363. doi: 10.1039/C5RA07613G.

41. Wu D, Sedgwick AC, Gunnlaugsson T, Akkaya EU, Yoon J, James TD. Fluorescent chemosensors: The past, present and future. Chem Soc Rev 2017; 46(23): 7105-23. doi: 10.1039/ C7CS00240H. 